Vol 41 (2016) No 184 193-211

\title{
Faculty's Academic Intellectual Leadership within the Conditions of Modern Universities
}

\author{
Barış Uslu ${ }^{1}$
}

\begin{abstract}
The purpose of this research is to examine the displayed level of faculty's academic intellectual leadership behaviors, and the differences according to their personal, professional, and institutional features, by controlling the impact of having managerial duties. For this purpose, quantitative data were collected from 1398 Turkish faculty using the Academic Intellectual Leadership Scale. The data were then analyzed using descriptive and covariance analyses. Descriptive analysis showed that the general level of the faculty's intellectual leadership behaviors was at a "Sometimes" level, while at a "Often" level in Mentor and Guardian dimensions. Moreover, the covariance analyses, by eliminating the impact of having managerial duties, showed that there were significant differences in the faculty's intellectual leadership in terms of their gender, seniority, academic title, discipline, and universities' establishment dates. These differences may arise from the willingness of the female members of the faculty to academic contributions, potentially larger scholarly productions of professors during their longer careers, the subjectivity of the research results in social sciences, and the well-rounded institutional facilities in the most of older universities to support academic activities. Therefore, in order to minimize the differences among faculty's intellectual leadership, university managers can adopt several practices such as providing larger travel funds for younger academics, creating inducement project opportunities early in the careers of the faculty, commissioning younger faculty with administrative duties and encouraging faculty from product-oriented disciplines to participate debates and activities related to social affairs as well as instituting essential academic support mechanisms.
\end{abstract}

Keywords

DOI: $10.15390 /$ EB.2016.6140

\section{Introduction}

The rapid growth in science and technology in the second half of 20th century resulted in the inception of the Information Age at the beginning of 21st century. During the Information Age, countries' economic advancement has become closely related to their knowledge production capacities (Olssen \& Peters, 2005). In addition, the latest theoretical and practical improvements related to human rights, democracy, equality, and multiculturalism have positively contributed to the development of social life in modern communities (Delanty, 2001). To progress these knowledge-

\footnotetext{
${ }^{1}$ Çanakkale Onsekiz Mart University, Faculty of Education, Department of Educational Sciences, Turkey, barisuslu@gmail.com
} 
based economic and social strides, universities have important duties such as training high-skilled human resources, sustaining advanced research projects for new products and leading social changes via their community engagement activities (Aypay, 2015). Furthermore, modernization improvements, such as mass (even universal) education, globalization, privatization, corporatization, and managerialism created new challenges for modern universities. To meet demands, universities must generate flexibility in degree programs to attract different student bodies, participate in national/international research collaborations, market their brands to increase their financial autonomy, and compete to obtain external funds (Macfarlane, 2012).

Universities have always relied on academics, as the primarily responsible human resource, in order to achieve these varied missions. With the mass higher education conditions after World War II, academics began to be seen as more than knowledge producers and public intellectuals, those are accepted as traditional academic roles in the elitist higher education understanding (Yllmaz, 2007). Furthermore, new challenges faced by modern universities have brought new responsibilities to academics such as developing innovative teaching methods, generating alternative resources, leading cooperation with government and industry, participating in international research networks, expanding research and teaching agendas with interdisciplinary activities, and representing disciplines and institutions internally and externally (Welch, 2005). In present times, the accomplishment of traditional duties and new responsibilities by academics is crucial not only for disciplinary or institutional advancement, but also for the development of economic and social welfare in their communities (Aypay, 2001). Scholars began researching these crucial academic roles; Macfarlane (2011) developed the term "Intellectual Leadership" to indicate all sorts of behaviors displayed by academics in order to fulfill their duties and responsibilities, and categorized these behaviors in six dimensions: Role Model, Mentor, Acquisitor, Guardian, Ambassador and Advocate.

However, Turkish media recently emitted several articles which include undesirable cases in academia such as Insufficient Academics for Their Students (Keskin \& Burucu, 2013), Plagiarism Suicide (Aydın, 2012), and Citation Gang (Kaplan, 2014). These articles about academics" insufficient professional skills and unethical behaviors raised many serious questions in the society related to the fulfillment of academics' duties and responsibilities. Therefore, investigating academics' intellectual leadership, based on their self-assessment, can be the most appropriate way to respond to these concerns. As well as surveying the displayed level of the intellectual leadership behaviors of faculty (specifically those who have teaching, research and service duties), it is also important to discover influence of faculty's personal, professional and institutional characteristics on their academic intellectual leadership.

In Turkey, there are total of 190 universities among which 114 are public universities. Almost half of the public universities were established after 2005 (Özoğlu, Gür, \& Gümüs, 2016), mostly in less-developed regions; so universities' locations and establishment dates can be indicators related to their institutional and infrastructural development. This may lead them to be potential facilitators for faculty's intellectual leadership behaviors. In addition, according to Aypay's (2001) and Yilmaz's (2007) studies, faculty's gender, seniority, titles, disciplines and managerial duties are some personal and professional features influencing their intellectual and scholarly performance. Among these specifications; however, formal administrative positions provide some advantages for faculty to benefit from institutional resources more extensively, and bring extra duties to represent their universities internal/external platforms (Uslu, 2015a). 
Accordingly, it is important to understand the influence of these factors on faculty's intellectual leadership by controlling for the impact of managerial roles. This helps generating suggestions to maximize these faculty's intellectual leadership behaviors within the conditions of modern universities. In this regard, the purpose of this research is to examine the frequency of faculty's academic intellectual leadership behaviors, and the differences according to their personal, professional and institutional features by controlling the impact of having managerial duties. For this purpose, the research questions are:

1. What is the displayed level of faculty's academic intellectual leadership behaviors?

2. Controlling for the impact of having managerial duty, is there any significant difference among faculty's academic intellectual leadership in terms of their gender, seniority, titles and disciplines, and universities' establishment dates and locations?

\section{Literature Review}

\section{The Components of Academic Intellectual Leadership}

The literature on higher education includes several studies related to the academic profession and the expected roles from academics. However, a few of these studies attempted to form a terminology about academics' role behaviors. As an example, Macfarlane (2011) used the term "Intellectual Leadership" to define the informal sides of academics' leadership and categorized these behaviors. Macfarlane (2012) then elaborated his arguments related to this categorization. In addition, Macfarlane and Chan (2014) presented various examples related to behaviors within the dimensions of intellectual leadership. Therefore, to better understand the content of academic intellectual leadership, these dimensions were summarized below (as cited in Uslu, 2015a, p. 84-90).

Role Model covers personal characteristics (e.g., popular, served, good, commitment, involved, committed, helping, patient, and responsible) and virtues (e.g., energetic/industrious, strategic thinker, creative, innovative, decisiveness, true fighter, honest, humorous, co-operative, witty, charming, and modest), and scholarly attributes (e.g., authority, develop/developed, scientific, expert, effective, global, scholar, pioneering, influential, intellectual, impact, recognized, and respected) (Macfarlane \& Chan, 2014, p. 6-9). However, this dimension primarily emphasizes scholarly achievements and building a reputation based on research productivity and the impacts on disciplinary contexts. Other model behaviors are "academic and administrative expertise; fund raising and mentoring young staff; facilitating research of older staff; establishing national and international collaborations and obtaining funding for this; and providing earned income for the university" (Macfarlane, 2012, p. 92). Also, within the Role Model dimension, one finds others' understandings about the discipline and society, influencing others with personal virtues and leading them for success, committing to contribute to the development of students, colleagues, research fields, higher education institutions and society, and "coping with difficulties both in academic and personal life (such as economical, racial, sexual, religional, or ideological obstacles). As a result, a strong Role Model dimension will show academics who are the "Inspirational Teachers" with innovative teachinglearning initiatives, nationally and internationally "Respected Researchers" thanks to their influential scholarly products, "Capable Managers" for their disciplines and institutions, "Public Servants" contributing to social welfare with their expertise (Macfarlane, 2011; 2012; Macfarlane \& Chan, 2014), and "Daring Crusaders" overcoming all types of difficulties in their professional life. 
Mentor indicates contributing to the development of less experienced colleagues by guiding and facilitating their scholarly activities and nurturing their potential by way of collaborative studies. According to Macfarlane (2012, p. 93), "good mentorship involves helping people realize their own potential and putting their personal interests above those of the organization they are currently working for." On the other side, a) supervising or advising postgraduate students formally and informally by considering them to be the next generation in academia and b) preserving them from internal and external oppressions in academic institutions are the main mentoring activities of the senior academics. Therefore, in order to support younger academics to become independent intellectuals, senior academics should mentor their less-experienced colleagues as well as postgraduate students through their advice and contribution on various activities of early career academics/researchers such as research/project fund applications, scholarly publication attempts, cocomposition and co-authorship of research articles, formation of research teams with their participation, participation in fellowship activities, professional feedback about their teaching-learning practices, creation of co-advisor opportunities, discussion on their intellectual ideas, connections with pioneer academics in their disciplines, and guidance to form their long-term career plans (Macfarlane, 2011, 2012; Macfarlane \& Chan, 2014). At the end, the achievement in mentorship comes "when [...] the mentee is no longer intellectually dependent on the mentor and finds their own voice [...] mentor has succeeded when mentee no longer needs their support and guidance" (Macfarlane, 2012, p. 94).

Acquisitor (Enabler) implies that the senior academics have to acquire research grants, research and development (R\&D) contracts, patents and copyrights, alternative resources, and other commercial opportunities as an indispensable reality of corporatized, business-oriented, contemporary universities. These types of financial resources, for academics, provide greater power to influence others intellectually and to become more independent from the demands of their institutions, such as extra teaching responsibilities and administrative duties. In other words, "a professor without a research center, or at least in possession of research grants and doctoral students, is unlikely to be able to exercise as much intellectual influence over others" (Macfarlane, 2011, p. 69). Moreover, being an Acquisitor covers supporting young researchers and junior colleagues, and their research initiatives, financially by coordinating and leading project teams to obtain research funds. Furthermore, senior academics are important figures in establishing communication channels among younger researchers, effective faculty, and academic leaders in their discipline and introducing less experienced colleagues and students to academic platforms and networks such as research collaborations, journals, conferences, colloquiums, seminars, or lectures as coinvestigator/author/presenter or quest speakers (Macfarlane, 2012; Macfarlane \& Chan, 2014).

Being a Guardian (Steward) means to elevate academic values and standards in scholarly platforms and to contribute to the development of scientific fields in new directions by unprejudiced peer review activities. Academics carry out their Guardian roles mostly with gatekeeping duties (e.g., editing or peer-reviewing books and journals, assessing research grant proposals as panelists, and chairing sessions in academic events) and pro-bono activities (e.g., examining doctoral candidates in the dissertation period, reviewing colleagues' studies, taking responsibilities in disciplinary committees, and contributing to the university-wide research assessment commissions) (Macfarlane, 2011). As a natural process, when academics become more well-known in their field, their guardianship roles start to increase with newer parts in different editorial boards, scientific committees, and research councils (Macfarlane \& Chan, 2014). Moreover, one of the important parts for guardianship is to ensure that a set of academic values, norms, and standards are gained by doctoral candidates and potential faculty. As a result, "this element of guardianship is about ensuring continuity and the survival of disciplinary specialisms in an increasingly competitive world of epistemological fragmentation" (Macfarlane, 2012, p. 95). 
Ambassador emphasizes the academics' interest in representing higher education institutions in local, national, and even international platforms. When academics become more well-known figures in academia nationally and internationally, they can contribute more fully to the reputation of their institutions (Macfarlane \& Chan, 2014). Examples of activities promoting an academic's own reputation while they represent their disciplines and institutions could be participating in international foundations related to their expertise and interest; joining research collaborations with foreign universities; working with non-governmental organizations (NGOs); providing consultation to commercial enterprises; undertaking duties on national and international disciplinary commissions and boards; leading to organize academic events such as congress, colloquiums, and seminars; attending conferences as keynote speakers; making international visits to collaborate with foreign colleagues; writing about social issues in the popular press like journals, magazines, and newspapers; taking a seat in radio or television programs to inform the public related to their expertise; and winning prestigious awards or prizes (Macfarlane, 2011). Moreover, these activities contribute to the reputation of their institutions, whereby creating universities that have higher public and sectorial profiles. In this manner, there are some conjunctions between the Ambassador and Advocate roles of academics, and "being Ambassador, though, implies promoting the university and the department, whereas being an Advocate was associated more closely with promoting conceptual and socio-political perspectives often connected closely with the discipline" (Macfarlane, 2012, p. 98).

Macfarlane (2012, p. 86) states that "the professor as Advocate might seek to promote understanding and acceptance of alternative theoretical paradigm in their discipline $[\ldots]$ the professor as Advocate might be more of a public activist campaigning for changes in public policy." Advocate, thus, means to develop a vision or alternative ways for changing the existing conditions in academia and to serve the community by using disciplinary knowledge, ideas, theories, models, and arguments. In this regard, being an Advocate designates two aspects: a) emphasizing the importance of a discipline and contributing its value by benefiting from disciplinary expertise in an institutional services, and $b$ ) applying theoretical information and practical experiences based on their scholarly activities toward the solution of social problems (Macfarlane, 2011; 2012). Academics, in the first aspect, can explain main ideas related to their subjects, promote key points of their scholarly products, discuss topics of their expertise in disciplinary and interdisciplinary context, and lobby inside and outside of their institutions on behalf of their field. In the other aspect, academics as an Advocate should influence public debates by transferring their knowledge, ideas, and suggestions to people via local, national and even international publications, radio, and television programs or internet broadcast facilities, and participate in social campaigns related to their scholarly interests by adapting theoretical understandings of their disciplines to eliminate conflicts in communities (Macfarlane, 2012; Macfarlane \& Chan, 2014).

\section{Studies Related to Academic Intellectual Leadership}

Historically, leadership discourses started with the "Great Man" approach and have continued with the development of many leadership theories that emphasize the leadership of one person as a heroic leader (Arslan \& Uslu, 2014; Northouse, 2007). Therefore, leadership literature in higher education has been dominated by studies related to the characteristics and behaviors of formal leaders such as presidents, vice-chancellors, or rectors of universities. On the other hand, there are a limited number of studies related to academics' intellectual leadership behaviors both in international and national literature of higher education, despite vigorous accentuation of the importance of academics' informal leadership (Rayner, Fuller, McEwen, \& Roberts, 2010). 
One of the prominent studies related to the roles of faculty was carried out in 1990 by the Carnegie Foundation in the United States of America (USA). Based on the results of this study, Boyer (1990) categorized faculty's role behaviors into four dimensions: Scholarship of Teaching (developing pedagogical practices and knowledge and transferring them to others to improve their teaching and abilities), Scholarship of Discovery (exploring new knowledge, theories, principles, critiques, and spreading these creations in scholarly platforms), Scholarship of Integration (making new connections between different fields by producing interdisciplinary knowledge and bringing new comprehensions into other fields besides their own), and Scholarship of Application (benefiting from the disciplinary knowledge to solve significant individual, institutional, and societal problems and using expertise for the development and change of the community). Aypay (2001) then used this framework to evaluate faculty's role performances and to explore the relations between faculty's performances and the organizational structures of US universities. He found that 19\% variance for Scholarship of Discovery, $16 \%$ variance for Scholarship of Integration, 17\% variance for Scholarship of Application, and 11\% variance for Scholarship of Teaching were explained by faculty's personal, professional, and institutional features.

In the United Kingdom (UK), The National Conference of University Professors was held in 1991, and the standards of professoriate were specified as Established Chairs, Personal Chairs, Academic Standing, Research and Scholarship, Teaching, Acquisition of Resources, Powers of Communication, Services to the Wider University Community, and Services outside the University (NCUP, 1991). In line with these standards, Tight (2002) in his famous study What does it mean to be a professor? defined 9 major professorial roles: being a role model, helping other colleagues to develop, generating income, influencing public debate, influencing the work and direction of the university, leadership in research, leadership in teaching, representing the department in the university, and upholding standards of scholarship. Macfarlane (2011) then used these major professorial roles to compare the professional priorities of full-time professors in the UK and the expectations of their institutions. After the interviews with the UK professors and the application of an online questionnaire, he discovered several differences between the professors' and universities' priorities and stated that first five prior behaviors for professors were helping other colleagues to develop, leadership in research, being a role model, upholding standards of scholarship, and influencing the work and direction of the university, while first five prior behaviors for universities were leadership in research, generating income, upholding standards of scholarship, helping other colleagues to develop, and being a role model.

Macfarlane (2012) also conjoined his analytical results with the analysis of academic obituaries to generate his book Intellectual leadership in higher education: Renewing the role of the university professor. He claimed that professorial intellectual leadership is the combination of Academic Freedom (being a critic and advocate) and Duties of Senior Academics (being a mentor, guardian, enabler, and ambassador). He also proposed a model for intellectual leadership with two axes: Discipline and Society. The Discipline axis indicates professorial roles behaviors within Knowledge Producer and Boundary Transgressor, while the Society axis indicates behaviors within Academic Citizen and Public Intellectual. Macfarlane and Chan (2014) then published the results of the obituary analysis. They used academic obituaries, between 2008 and 2010, from the Times Higher Education to explore different types of intellectual leadership behaviors displayed by famous academics and their personal and scholarly characteristics. 
Additionally, Evans (2012, p. 428) explained that the researcher development process has three components: Behavioural Development (processual, procedural, productive, and competential change), Attitudinal Development (perceptual, evaluative, and motivational change), and Intellectual Development (epistemological, rationalistic, comprehensive, and analytical change) and affirmed that professors, as distinguished figures in their disciplines and profession, have much responsibilities to assist the development of the careers of early academics as qualified researchers. Moreover, Evans, Homer, and Rayner (2013) examined the opinions of non-professorial academics towards professorial leadership in UK universities by using an online survey. They discovered that nearly one out of four younger academics had experiences related to professorial leadership at an exemplary level, but most of them expected professors to show greater effort to help their professional development.

In the Turkish context, Yilmaz (2007) investigated only the intellectual leadership of senior managers (rectors, deans, head of departments, and graduate school managers). He categorized academic managers' behaviors and activities into four dimensions: i) giving lectures, ii) producing publications, iii) being a public voice, and iv) being a global opinion organizer. On a 7-Point Likert Scale, he found that academic managers' leadership behaviors were at a high level in terms of being an intellectual role model for students in their lectures, advising students' studies as a way to reach new information sources, acting as a public voice, using universities as public discussion platforms, acting as a global opinion organizer, encouraging other academics to be global opinion organizers, transferring their intellectual characteristics into academic life, and respecting other academics' intellectual behaviors while being a writer to intellectual publication was at a medium level.

In other studies, Uslu (2015a; 2015b) evaluated the displayed level of intellectual leadership behaviors for the Turkish faculty in accordance with the dimensions in Macfarlane's (2011) study. He also examined the personal, professional, and institutional factors causing the differences among the faculty's intellectual leadership, and the relations between their leadership behaviors and organizational features of universities. Furthermore, Uslu and Arslan (2015) investigated the relations between faculty's intellectual leadership and organizational communication, organizational climate, and managerial flexibility regarding scholarly practices (MFRSP) in universities. They explored that, whereas there were strong and significant correlations between the faculty's intellectual leadership and communication, climate, and MFRSP in universities, only organizational climate and MFRSP were predictors for the displayed level of faculty's intellectual leadership.

\section{Methodology}

This research was designed using a survey model in which "investigators ask questions about peoples' beliefs, opinions, characteristics, or behavior [...], and a survey researcher may want to investigate associations between respondents' characteristics such as age, education, social class, race, and their current attitudes toward some issue" (Ary, Jacobs, Razavieh, \& Sorensen, 2006, p. 400). In this study, the researcher collected quantitative data from the Turkish faculty to discover the personal, professional, and institutional factors influencing their academic intellectual leadership behaviors.

\section{Population and Sample}

The faculty, as senior academics having teaching, research, and service duties together, was included in the target population. Research assistants, lecturers, and instructors were excluded because lecturers and instructors do not have research duty among their primary responsibilities and research assistants do not have teaching duty. Also, faculty who work in foundation universities were excluded in the sample because of the managerial, operational, and financial differences between public and foundation universities. Therefore, the population was limited to the 47294 faculty who work in Turkish public universities (15702 female faculty [33.20\%] and 31592 male faculty [66.80\%]; 15237 professors [32.22\%], 9490 associate professors [20.07\%], and 22567 assistant professors [47.72\%]) (YÖK, 2015). 
Incorporating population-based sampling, the researcher sought to reach faculty as much as possible via e-mail, which contained an online questionnaire link. For this reason, contact information (address, telephone number, and e-mail) of the faculty who were registered on the Researchers Information System, Turkey were accessed (ARBİS, 2015). The online questionnaire was filled out by 1398 faculty (See Table 1). This sample was adequate to represent the population of the research with $99 \%$ confidence level and \pm 2 confidence interval (Cohen, Manion, \& Morrison, 2007, p. 104).

Table 1. Distribution of Faculty According to Their Personal, Professional and Institutional Features

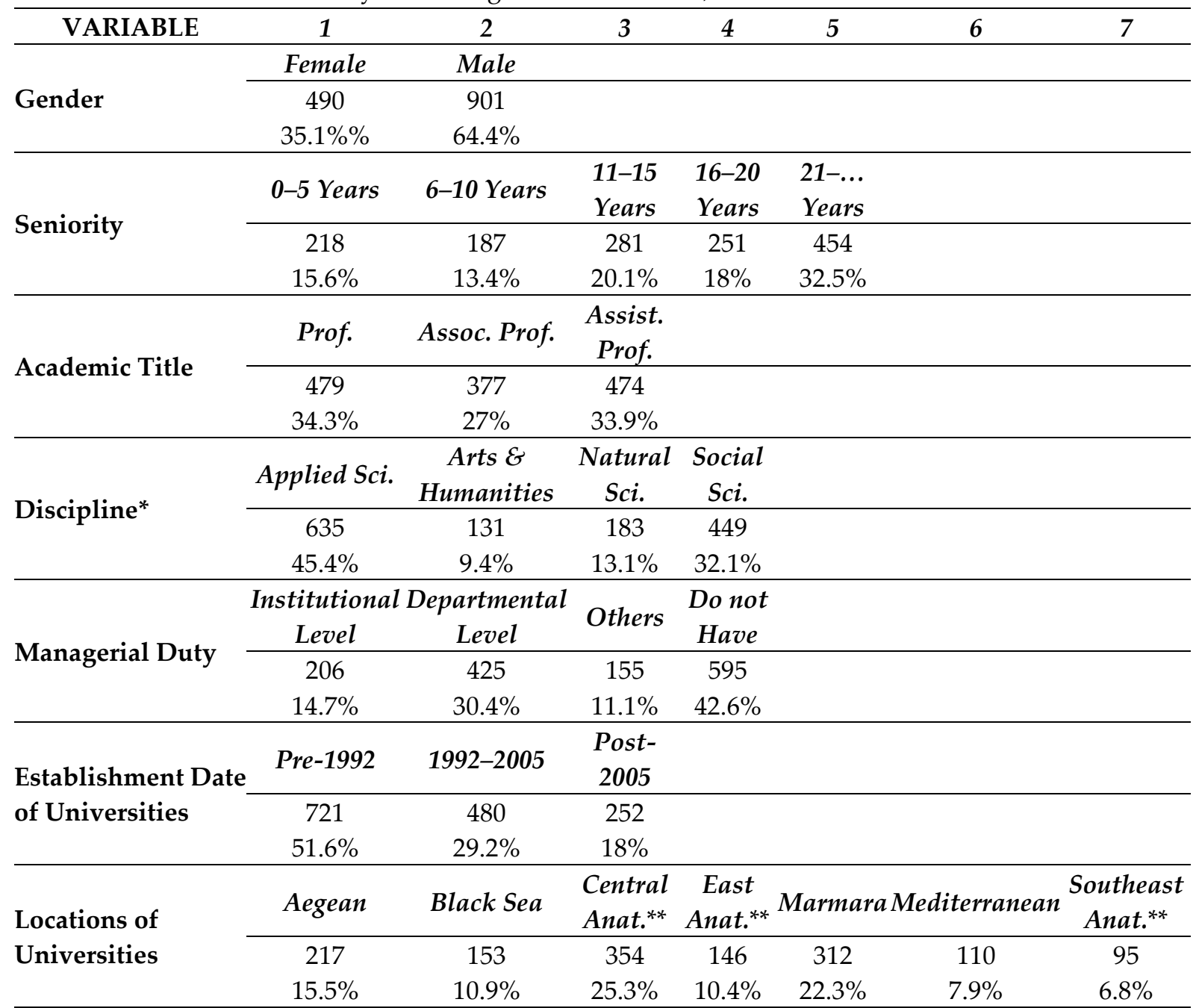

${ }^{*}$ Faculty's disciplines were categorized in accordance with Biglan Disciplinary Model (as cited in Chynoweth, 2009, p. 304)

** Anat. = Anatolia (Central Anatolia, East Anatolia, and Southeast Anatolia)

\section{Data Collection Instrument}

Academic Intellectual Leadership Scale (AILS): This scale was developed by Uslu (2015b) according to the dimensions of intellectual leadership in Macfarlane's (2011) study. AILS is composed of 20 items within five dimensions (Ambassador, Mentor, Acquisitor, Guardian, and Advocate), and each dimension contains four items. AILS's items have factor loadings between 0.553 and 0.848 , and it explains $64.83 \%$ of the variance for faculty's intellectual leadership. Uslu (2015b) calculated the reliability coefficient as 0.906 by using Cronbach's alpha. In this research, AILS's reliability was found $\alpha=0.916$ as an indicator of a highly reliable scale. Furthermore, by taking Chi-Square/Degree of Freedom $\left(\chi^{2} / \mathrm{df}\right)<5$, Goodness of Fit Index (GFI) $>0.90$, Adjusted Goodness of Fit Index (AGFI) $>0.85$, Comparative Fit Index (CFI) $>0.90$, and Root Mean Square Error of Approximation (RMSEA) $<0.08$ as the criteria for model fit indexes (Hair, Black, Babin, \& Anderson, 2010; İlhan \& Çetin, 2014), the researcher examined AILS's factorial structure with Confirmatory Factor Analysis (CFA). The model fit indexes related to AILS in this research were found as $\chi^{2} / \mathrm{df}=4.923, \mathrm{GFI}=0.95$, AGFI $=0.928, \mathrm{CFI}=$ 0.953 , and RMSEA $=0.053$ (as indicators of an acceptable model fit). 


\section{Data Collection and Analysis}

The data were collected via an online questionnaire, which contained AILS and several questions related to the faculty's personal, professional, and institutional features. The items of AILS were designed in a 5-Point Likert Scale Style and scored by respondents as Never $=1$, Rarely $=2$, Sometimes $=3$, Often $=4$, and Always $=5$. During the data analysis, the researcher used the Statistical Package for the Social Sciences (SPSS) 21.0 (for descriptive, differential, and covariance analyses), and the Analysis of Moment Structures (AMOS) 20.0 (for CFA) softwares. To assess normal distribution, Skewness and Kurtosis values were employed, and coefficients were found between -1.099 and 0.781 as evidence for the normal distribution of data (Bayat, 2014; Can, 2014). Parametric analysis techniques (with 0.05 reference point) were then employed to investigate the differentiations among the displayed level of the faculty's intellectual leadership behaviors in terms of their personal, professional, and institutional features, after controlling for the impact of having managerial duty. At first, descriptive analysis was used to determine the frequency of faculty's intellectual leadership behaviors. ANCOVA Analysis (by using Bonferroni Test to discover the source of differences) was then performed to discover significant differences among faculty's intellectual leadership after satisfying the preconditions of covariant analysis: a) the independence of the covariate and treatment effect and b) homogeneity of regression slopes (Field, 2009). First, the independence of the covariate was examined by visual inspection of graphics (scattered plots) of dependent variable $=$ academic intellectual leadership (because of categorical covariate variable $=$ having managerial duties and independent variables $=$ gender, seniority, titles, disciplines, establishment dates, and locations of universities). These graphs showed that the values of dependent variable are parallel and independent within each category of the covariate for all independent variables. In addition, the results shown in Table 2 show the homogeneity of regression slopes for the covariant and each of independent variables.

Table 2. The Analysis Results Related to the Homogeneity of Regression Slopes for Research Variables

\begin{tabular}{lccccc}
\hline SOURCE & Sum of Squares & df & Mean Square & F & $\mathbf{p}^{\text {** }}$ \\
\hline Gender * Having Managerial Duty & 0.005 & 1 & 0.005 & 0.01 & 0.92 \\
Seniority * Having Managerial Duty & 1.347 & 4 & 0.337 & 0.663 & 0.62 \\
Title * Having Managerial Duty & 0.47 & 2 & 0.235 & 0.461 & 0.63 \\
Discipline * Having Managerial Duty & 0.83 & 3 & 0.286 & 0.522 & 0.62 \\
Establishment Dates of Universities * & 0.009 & 2 & 0.004 & 0.008 & 0.99 \\
Having Managerial Duty & & & & & \\
Locations of Universities * Having & \multirow{2}{*}{3.125} & 6 & 0.521 & 1.007 & 0.42 \\
Managerial Duty & & &
\end{tabular}

** All of $p$ values are $>0.05$ as evidence for the homogeneity of regression slope. 


\section{Findings}

The first research question is "What is the displayed level of faculty's academic intellectual leadership behaviors?." To produce results related to the question, descriptive analysis was performed. The findings indicating the frequency of faculty's academic intellectual leadership behaviors within five dimensions are presented in Table 3.

Table 3. Descriptive Statistics Related to Faculty's Academic Intellectual Leadership ( $\mathrm{n}=1398$ )

\begin{tabular}{cccccccccccc}
\hline Academic Intellectual Leadership & \multicolumn{2}{c}{ Mentor } & \multicolumn{2}{c}{ Acquisitor } & \multicolumn{2}{c}{ Guardian } & \multicolumn{3}{c}{ Ambassador } & Advocate \\
\hline Mean* & sd & Mean* & sd & Mean* & sd & Mean* & sd & Mean* & sd & Mean* & sd \\
3.38 & 0.74 & 3.72 & 0.86 & 3.24 & 1.02 & 3.85 & 0.77 & 3.07 & 0.98 & 3.03 & 1 \\
\hline
\end{tabular}

*1.00-1.79 = Never; $1.80-2.59$ = Rarely; $2.60-3.39$ = Sometimes; $3.40-4.19$ = Often; 4.20-5.00 = Always

According to the findings in Table 3, the general frequency of faculty's academic intellectual leadership behaviors fell into 'Sometimes' level $(\bar{X}=3.38$; sd $=0.74)$. Moreover, faculty's intellectual leadership behaviors within Mentor $(\bar{X}=3.72$; sd $=0.86)$ and Guardian $(\bar{X}=3.85$; $\mathrm{sd}=0.77)$ dimensions were in the 'Often' level while others were in the 'Sometimes' level (in Acquisitor: $\bar{X}=3.24$; sd $=1.02$, in Ambassador: $\bar{X}=3.07$; sd $=0.98$, and in Advocate: $\bar{X}=3.03 ; \mathrm{sd}=1$ ).

Another research question is "Controlling for the impact of having managerial duty, is there any significant difference among faculty's academic intellectual leadership in terms of their gender, seniority, titles, and disciplines, and universities' establishment dates and locations?" Before examining the differences among faculty's intellectual leadership, the influence of having managerial duties was firstly checked by using ANOVA (See Table 4). After checking the impact of having managerial duties, the differentiations within the displayed level of faculty's intellectual leadership in terms of faculty's personal, professional, and institutional features were explored by equalizing the impact of having managerial duties on these behaviors.

Table 4. ANOVA Results of Faculty's Intellectual Leadership According to Their Managerial Duties

\begin{tabular}{|c|c|c|c|c|c|c|c|}
\hline $\begin{array}{l}\text { VARIABLE } \\
\text { (Managerial } \\
\text { Duty) }\end{array}$ & $\begin{array}{l}\text { Sum of } \\
\text { Squares } \\
\text { (Total) }\end{array}$ & df & $\begin{array}{l}\text { Mean } \\
\text { Square }\end{array}$ & $\mathbf{F}$ & $\mathrm{p}^{*}$ & $\eta^{2 * *}$ & $\begin{array}{c}\text { Differences } \\
\begin{array}{c}\text { (1=Inst. Level; 2=Depart. Level; } \\
\text { 3=Others; 4=Don't Have) }\end{array}\end{array}$ \\
\hline $\begin{array}{l}\text { Academic } \\
\text { Intellectual } \\
\text { Leadership }\end{array}$ & 751.374 & $3 / 1377$ & $\begin{array}{c}12.201 \\
0.519\end{array}$ & 23.504 & $0.00^{*}$ & 0.06 & $\begin{aligned} 2 & <1 \\
3 & <1 \\
4<1 ; 4 & <2 ; 4<3\end{aligned}$ \\
\hline Mentor & 1031.29 & $3 / 1377$ & $\begin{array}{l}3.669 \\
0.741\end{array}$ & 4.952 & $0.00^{*}$ & 0.01 & $4<1 ; 4<2$ \\
\hline Acquisitor & 1431.468 & $3 / 1377$ & $\begin{array}{c}11.418 \\
1.015\end{array}$ & 11.253 & $0.00^{*}$ & 0.02 & $\begin{array}{c}2<1 \\
4<1 ; 4<2 ; 4<3\end{array}$ \\
\hline Guardian & 823.47 & $3 / 1377$ & $\begin{array}{c}2.69 \\
0.592\end{array}$ & 4.452 & $0.00^{*}$ & 0.01 & $4<2$ \\
\hline Ambassador & 1321.944 & $3 / 1377$ & $\begin{array}{c}35.589 \\
0.882\end{array}$ & 40.329 & $0.00^{*}$ & 0.09 & $\begin{aligned} 2 & <1 \\
3 & <1 \\
4<1 ; 4 & <2 ; 4<3\end{aligned}$ \\
\hline Advocate & 1387.122 & $3 / 1377$ & $\begin{array}{c}24.387 \\
0.954\end{array}$ & 25.557 & $0.00^{*}$ & 0.06 & $\begin{aligned} 2 & <1 \\
3 & <1 \\
4<1 ; 4 & <2 ; 4<3\end{aligned}$ \\
\hline
\end{tabular}

${ }^{*} \mathrm{p} \leq 0.05 ;{ }^{* *} 0.000-0.059$ = very small effect, $0.060-0.139=$ moderate effect, $0.140-\ldots=$ very large effect 
Table 4 shows that, according to faculty's managerial duties, there were significant differences

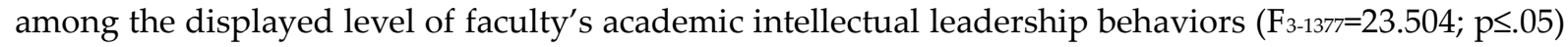
within all dimensions (in Mentor: $\mathrm{F}_{3-1377}=4.952 ; \mathrm{p} \leq 0.05$, in Acquisitor: $\mathrm{F}_{3-1377}=11.253 ; \mathrm{p} \leq 0.05$, in Guardian: $\mathrm{F}_{3-1377}=4.452 ; \mathrm{p} \leq 0.05$, in Ambassador: $\mathrm{F}_{3-1377}=40.329 ; \mathrm{p} \leq 0.05$ and in Advocate: $\mathrm{F}_{3-1377}=25.557 ; \mathrm{p}$ $\leq 0.05$ ). This indicates a higher frequency among academic managers at institutional level like rector, vice-rector, dean, vice-dean, manager and vice-manager of institute or higher education school. In addition, faculty's managerial duties have a strong effect on their intellectual leadership $\left(\eta^{2}=0.06\right)$; the leading dimensions affecting this differentiation are Ambassador $\left(\eta^{2}=0.09\right)$ and Advocate $\left(\eta^{2}=0.06\right)$.

In line with these results, managerial duties were designated as a covariant variable. ANCOVA analyses were then performed to investigate the differences among faculty's intellectual leadership in terms of their gender, seniority, title, discipline, and universities' establishment dates and locations. ANCOVA results are presented in Table 5-10.

Table 5. ANCOVA Results of Faculty's Intellectual Leadership in Terms of Their Gender

\begin{tabular}{lllcllc}
\hline VARIABLE (Gender) & $\begin{array}{l}\text { Sum of } \\
\text { Square }\end{array}$ & df & $\begin{array}{c}\text { Mean } \\
\text { Square }\end{array}$ & F & p $^{*}$ & $\begin{array}{c}\text { Differences } \\
\text { (1=Female; 2=Male) }\end{array}$ \\
\hline Academic Intellectual Leadership & 3.715 & $1 / 1378$ & 3.715 & 7.177 & $0.01^{*}$ & $2<1$ \\
Mentor & 6.331 & $1 / 1378$ & 6.331 & 8.559 & $0.00^{*}$ & $2<1$ \\
Acquisitor & 0.564 & $1 / 1378$ & 0.564 & 0.554 & 0.46 & \\
Guardian & 6.067 & $1 / 1378$ & 6.067 & 10.296 & $0.00^{*}$ & $2<1$ \\
Ambassador & 8.642 & $1 / 1378$ & 8.642 & 9.736 & $0.00^{*}$ & $2<1$ \\
Advocate & 0.935 & $1 / 1378$ & 0.935 & 0.982 & 0.32 & \\
\hline
\end{tabular}

${ }^{*} \mathrm{p} \leq 0.05$

Table 5 reports that, in terms of gender there were significant differences among the corrected means (by controlling for the impact of managerial duties) of faculty's intellectual leadership $\left(\mathrm{F}_{1-1378}=\right.$ 7.177; $\mathrm{p} \leq 0.05)$. This showed especially within Mentor $\left(\mathrm{F}_{1-1378}=8.559 ; \mathrm{p} \leq 0.05\right)$, Guardian $\left(\mathrm{F}_{1-1378}=10.296\right.$; $\mathrm{p} \leq 0.05$ ) and Ambassador ( $\left.\mathrm{F}_{1-1378}=9.736 ; \mathrm{p} \leq 0.05\right)$ dimensions. Female faculty displayed these behaviors $\left(\bar{X}_{\text {Female }}=3.45 ; \mathrm{sd}=0.73\right.$ for Academic Intellectual Leadership, $\bar{X}_{\text {Female }}=3.81 ; \mathrm{sd}=0.86$ for Mentor, $\bar{X}_{\text {Female }}=$ 3.94; $\mathrm{sd}=0.75$ for Guardian and $\bar{X}_{\text {Female }}=3.18$; $\mathrm{sd}=0.98$ for Ambassador) significantly more often than male faculty.

Table 6. ANCOVA Results of Faculty's Intellectual Leadership in Terms of Their Seniority

\begin{tabular}{|c|c|c|c|c|c|c|}
\hline $\begin{array}{l}\text { VARIABLE } \\
\text { (Seniority) }\end{array}$ & $\begin{array}{l}\text { Sum of } \\
\text { Square }\end{array}$ & df & $\begin{array}{l}\text { Mean } \\
\text { Square }\end{array}$ & $\mathbf{F}$ & $\mathrm{p}^{*}$ & $\begin{array}{c}\text { Differences } \\
\begin{array}{c}\text { (1=0-5 Years; 2=6-10 Years; 3=11-15 Years; } \\
\text { 4=16-20 Years; 5=21-... Years) }\end{array}\end{array}$ \\
\hline $\begin{array}{l}\text { Academic Intellectual } \\
\text { Leadership }\end{array}$ & 19.529 & $4 / 1379$ & 4.882 & 9.618 & $0.00^{*}$ & $\begin{array}{c}1<4 ; 1<5 \\
3<5\end{array}$ \\
\hline Mentor & 20.171 & $4 / 1379$ & 5.043 & 6.928 & $0.00^{*}$ & $\begin{array}{c}1<3 ; 1<5 \\
3<5\end{array}$ \\
\hline Acquisitor & 26.421 & $4 / 1379$ & 6.605 & 6.596 & $0.00^{*}$ & $\begin{aligned} 1<2 ; 1 & <4 ; 1<5 \\
3 & <5\end{aligned}$ \\
\hline Guardian & 15.487 & $4 / 1379$ & 3.872 & 6.64 & $0.00^{*}$ & $\begin{aligned} 1<2 ; 1 & <4 ; 1<5 \\
3 & <5\end{aligned}$ \\
\hline Ambassador & 10.602 & $4 / 1379$ & 2.651 & 2.986 & $0.02^{*}$ & $\begin{array}{c}3<5 \\
1<4 ; 1<5\end{array}$ \\
\hline Advocate & 44.661 & $4 / 1379$ & 11.165 & 12.085 & $0.00^{*}$ & $\begin{array}{c}2<5 \\
3<4 ; 3<5\end{array}$ \\
\hline
\end{tabular}

${ }^{*} \mathrm{p} \leq 0.05$ 
According to Table 6, in terms of their seniority there were significant differences among the corrected means of faculty's intellectual leadership $\left(\mathrm{F}_{4-1379}=9.618 ; \mathrm{p} \leq 0.05\right)$ within all dimensions (in Mentor: $\mathrm{F}_{4-1379}=6.928 ; \mathrm{p} \leq 0.05$, in Acquisitor: $\mathrm{F}_{4-1379}=6.596 ; \mathrm{p} \leq 0.05$, in Guardian: $\mathrm{F}_{4-1379}=6.64 ; \mathrm{p} \leq 0.05$, in Ambassador: $\mathrm{F}_{4-1379}=2.986 ; \mathrm{p} \leq 0.05$, and in Advocate: $\left.\mathrm{F}_{4-1379}=12.085 ; \mathrm{p} \leq 0.05\right)$. All of these differences occurred more often with faculty having higher seniority $\left(\bar{X}_{21} \ldots\right.$ Years $=3.51$; sd $=0.73$ for Academic Intellectual Leadership, $\bar{X}_{21 \ldots} \ldots$ Years $=3.85$; $\mathrm{sd}=0.82$ for Mentor, $\bar{X}_{21} \ldots$ Years $=3.36$; $\mathrm{sd}=1.01$ for Acquisitor, $\bar{X}_{21}$ $\ldots$. Years $=3.95 ; \mathrm{sd}=0.76$ for Guardian, $\bar{X}_{21} \ldots$ Years $=3.17 ; \mathrm{sd}=1.02$ for Ambassador and $\bar{X}_{21} \ldots$ Years $=3.24 ; \mathrm{sd}=0.98$ for Advocate).

Table 7. ANCOVA Results of Faculty's Intellectual Leadership in Terms of Their Title

\begin{tabular}{lcccccc}
\hline VARIABLE (Title) & $\begin{array}{c}\text { Sum of } \\
\text { Square }\end{array}$ & $\mathbf{d f}$ & $\begin{array}{c}\text { Mean } \\
\text { Square }\end{array}$ & $\mathbf{F}$ & $\mathbf{p}^{*}$ & $\begin{array}{c}\text { Differences } \\
\text { (1 = Assist. Prof.; } \mathbf{2} \text { = Assoc. Prof.; } \\
\text { 3 = Prof.) }\end{array}$ \\
\hline $\begin{array}{l}\text { Academic Intellectual } \\
\text { Leadership }\end{array}$ & 13.88 & $2 / 1317$ & 6.94 & 13.603 & $0.00^{*}$ & $\begin{array}{c}1<3 \\
2<3 \\
\text { Mentor }\end{array}$ \\
Acquisitor & 9.664 & $2 / 1317$ & 4.832 & 6.601 & $0.00^{*}$ & $1<3$ \\
Guardian & 21.483 & $2 / 1317$ & 10.742 & 10.638 & $0.00^{*}$ & $\begin{array}{c}1<3 \\
1<2 ; 1<3 \\
2<3\end{array}$ \\
Ambassador & 20.064 & $2 / 1317$ & 10.032 & 17.438 & $0.00^{*}$ & $1<3$ \\
Advocate & 2.933 & $2 / 1317$ & 1.467 & 1.659 & 0.19 & $2<3$ \\
\hline
\end{tabular}

${ }^{*} \mathrm{p} \leq 0.05$

The results in Table 7 indicate that, in terms of academic title there were significant differences among the corrected means of faculty's intellectual leadership $\left(\mathrm{F}_{2-1317}=13.603 ; \mathrm{p} \leq 0.05\right)$ within all dimensions except in the Ambassador (in Mentor: $\mathrm{F}_{2-1317}=6.601 ; \mathrm{p} \leq 0.05$, in Acquisitor: $\mathrm{F}_{2-1317}=10.638 ; \mathrm{p} \leq$ 0.05, in Guardian: $\mathrm{F}_{2-1317}=17.438 ; \mathrm{p} \leq 0.05$, and in Advocate: $\mathrm{F}_{2-1317}=13.775 ; \mathrm{p} \leq 0.05$, whereas in Ambassador $\left.\mathrm{F}_{2-1317}=1.659 ; \mathrm{p}>0.05\right)$. Professors generally displayed these behaviors $\left(\bar{X}_{\text {Prof }}=3.51 ; \mathrm{sd}=0.71\right.$ for Academic Intellectual Leadership, $\bar{X}_{\text {Prof }}=3.83$; sd $=0.83$ for Mentor, $\bar{X}_{\text {Prof }}=3.39$; sd $=0.95$ for Acquisitor, $\bar{X}_{\text {Prof }}=3.99 ; \mathrm{sd}=0.71$ for Guardian and $\bar{X}_{\text {Prof }}=3.21 ; \mathrm{sd}=0.98$ for Advocate) more often than others.

Table 8. ANCOVA Results of Faculty's Intellectual Leadership in Terms of Their Discipline

\begin{tabular}{lcccccc}
\hline $\begin{array}{l}\text { VARIABLE } \\
\text { (Discipline) }\end{array}$ & $\begin{array}{l}\text { Sum of } \\
\text { Square }\end{array}$ & df & $\begin{array}{c}\text { Mean } \\
\text { Square }\end{array}$ & F & $\mathbf{p}^{*}$ & $\begin{array}{c}\text { Differences } \\
(\mathbf{1}=\text { Applied Sci.; } 2 \text { = Arts \& Hum.; } \\
\text { 3= Natural Sci.; }=\text { Social Sci.) }\end{array}$ \\
\hline $\begin{array}{l}\text { Academic Intellectual } \\
\text { Leadership }\end{array}$ & 3.999 & $3 / 1345$ & 1.333 & 2.693 & $0.05^{*}$ & $1<4$ \\
$\begin{array}{l}\text { Mentor } \\
\text { Acquisitor }\end{array}$ & 7.816 & $3 / 1345$ & 2.605 & 3.258 & $0.02^{*}$ & $1<4$ \\
Guardian & 8.257 & $3 / 1345$ & 2.752 & 2.942 & $0.03^{*}$ & $2<3$ \\
Ambassador & 5.988 & $3 / 1345$ & 1.996 & 3.586 & $0.01^{*}$ & $1<4$ \\
Advocate & 6.228 & $3 / 1345$ & 2.076 & 2.626 & $0.05^{*}$ & - \\
& 15.893 & $3 / 1345$ & 5.298 & 5.683 & $0.00^{*}$ & $3<4$ \\
\hline
\end{tabular}

* $\mathrm{p} \leq 0.05$ 
Table 8 reports that, in terms of academic discipline there were significant differences among the corrected means of faculty's intellectual leadership ( $\left.\mathrm{F}_{3-1345}=2.693 ; \mathrm{p} \leq 0.05\right)$ within all dimensions (in Mentor: $\mathrm{F}_{3-1345}=3.258 ; \mathrm{p} \leq 0.05$, in Acquisitor: $\mathrm{F}_{3-1345}=2.942 ; \mathrm{p} \leq 0.05$, in Guardian: $\mathrm{F}_{3-1345}=3.586 ; \mathrm{p} \leq$ 0.05, in Ambassador: $\mathrm{F}_{3-1345}=2.626 ; \mathrm{p} \leq 0.05$, and in Advocate: $\mathrm{F}_{3-1345}=5.683 ; \mathrm{p} \leq 0.05$ ). It is of interest that the differences among faculty who work in social sciences displayed more often the intellectual leadership behaviors $\left(\bar{X}_{\text {soc.Sci. }}=3.37\right.$; sd $=0.71$ for Academic Intellectual Leadership $)$ within Mentor $\left(\bar{X}_{\text {Soc.Sci. }}=3.58 ; \mathrm{sd}=0.94\right)$, Guardian $\left(\bar{X}_{\text {Soc.Sci. }}=3.91 ; \mathrm{sd}=0.71\right)$, Advocate $\left(\bar{X}_{\text {soc.Sci. }}=3.06 ; \mathrm{sd}=0.97\right)$ and Ambassador (couldn't discover the source of difference), whereas faculty from natural sciences were more prone to report behaviors within Acquisitor $\left(\bar{X}_{\text {Nat.Sci. }}=3.36\right.$; sd $\left.=0.94\right)$ dimension.

Table 9. ANCOVA Results of Faculty's Intellectual Leadership in Terms of Universities' Establishment Dates

\begin{tabular}{lcccccc}
\hline $\begin{array}{l}\text { VARIABLE (Universities' } \\
\text { Establishment Years) }\end{array}$ & $\begin{array}{c}\text { Sum of } \\
\text { Square }\end{array}$ & df & $\begin{array}{c}\text { Mean } \\
\text { Square }\end{array}$ & F & $\mathbf{p}^{*}$ & $\begin{array}{c}\text { Differences } \\
(\mathbf{1}=\text { Pre-1992; 2 = 1992-2005; } \\
\text { 3 = Post-2005) }\end{array}$ \\
\hline $\begin{array}{l}\text { Academic Intellectual } \\
\text { Leadership }\end{array}$ & 4.001 & $2 / 1368$ & 2.001 & 3.864 & $0.02^{*}$ & $3<1$ \\
$\begin{array}{l}\text { Mentor } \\
\text { Acquisitor }\end{array}$ & 3.443 & $2 / 1368$ & 1.722 & 2.336 & 0.09 & \\
& 14.577 & $2 / 1368$ & 7.289 & 7.236 & $0.00^{*}$ & $2<1$ \\
Guardian & & & & & & $3<1$ \\
Ambassador & 7.802 & $2 / 1368$ & 3.901 & 6.644 & $0.00^{*}$ & $3<1$ \\
Advocate & 0.016 & $2 / 1368$ & 0.008 & 0.009 & 0.99 & $3<2$ \\
\hline
\end{tabular}

${ }^{*} \mathrm{p} \leq 0.05$

According to Table 9, in terms of universities' establishment years there were significant differences among the corrected means of faculty's intellectual leadership $\left(\mathrm{F}_{2-1368}=3.864 ; \mathrm{p} \leq 0.05\right)$ within the Acquisitor $\left(\mathrm{F}_{2-1368}=7.236 ; \mathrm{p} \leq 0.05\right)$ and Guardian $\left(\mathrm{F}_{2-1368}=6.644 ; \mathrm{p} \leq 0.05\right)$ dimensions. Generally, these differences showed up more often in faculty who work in pre-1992 universities $\left(\bar{X}_{\text {Pre- }}\right.$ $1992=3.43 ; \mathrm{sd}=0.72$ for Academic Intellectual Leadership, $\bar{X}_{\text {Pre-1992 }}=3.34 ; \mathrm{sd}=1.01$ for Acquisitor and $\bar{X}_{\text {Pre- }}$ $1992=3.91 ; \mathrm{sd}=.076$ for Guardian $)$.

Table 10. ANCOVA Results of Faculty's Intellectual Leadership in Terms of Universities' Locations

\begin{tabular}{lccccccc}
\hline $\begin{array}{l}\text { VARIABLE } \\
\begin{array}{l}\text { (Uni.e.,s' } \\
\text { Locations) }\end{array}\end{array}$ & $\begin{array}{c}\text { Sum of } \\
\text { Square }\end{array}$ & df & $\begin{array}{c}\text { Mean } \\
\text { Square }\end{array}$ & F & p $^{*}$ & $\begin{array}{c}\text { (1=Aegean; 2=Black Sea; 3=Central An.; } \\
\text { 4=East An.; 5=Marmara; } \\
\text { 6=Mediterranean; 7=Southeast An.) }\end{array}$ \\
\hline Acad. Int. Lead. & 6.05 & $6 / 1374$ & 1.008 & 1.949 & 0.07 & \\
Mentor & 7.287 & $6 / 1374$ & 1.214 & 1.651 & 0.13 & \\
Acquisitor & 13.265 & $6 / 1374$ & 2.211 & 2.188 & 0.06 & \\
Guardian & 3.866 & $6 / 1374$ & .644 & 1.09 & 0.37 & \\
Ambassador & 10.967 & $6 / 1374$ & 1.828 & 2.058 & 0.06 & \\
Advocate & 10.001 & $6 / 1374$ & 1.667 & 1.751 & 0.11 & \\
\hline
\end{tabular}
${ }^{*} \mathrm{p} \leq 0.05$

The last ANCOVA analysis shows that, in terms of universities' locations there was no significant difference among the corrected means of faculty's intellectual leadership according to universities locations $\left(\mathrm{F}_{6-1374}=1.949 ; \mathrm{p}>0.05\right)$. 


\section{Conclusion, Discussion, and Suggestions}

This research examined the displayed level of Turkish faculty's intellectual leadership behaviors based on their own assessments. Furthermore, the differentiations among the displayed level of faculty's intellectual leadership were explored in terms of their personal, professional, and institutional features, by controlling for the impact of their managerial duty conditions. The results were then discussed, and varied suggestions to minimize these differences are presented below.

First, the research reported that the general level of the faculty's intellectual leadership behaviors is at a medium level, while mentorship and guardianship behaviors are exhibited more often than the behaviors within other dimensions. Similarly, Uslu and Arslan (2015) and Uslu (2015a; 2015b) found the faculty's intellectual leadership within a medium level, whereas their activities towards disciplinary advancement were within a high level. Aypay (2001) also noted a low frequency of behaviors within Scholarship of Application (application, service to academia, service to society, application of knowledge, and service to institution). All of these results affirm that the faculty gives priority to the behaviors contributing in the advancement of their disciplines such as producing new seminal knowledge, maintaining the standards in profession and scientific areas, and helping their colleagues' academic development (Evans et al., 2013; Macfarlane, 2011). It can be asserted that the faculty, not only in Turkey but also around the world, generally focuses on their disciplinary publication and dissemination due to the main criterion of obtaining tenure: having a strong publication record. The faculty also prioritizes helping the development of their less experienced colleagues because of the contribution of advising younger researchers' studies in academic promotion, especially at the professoriate level (Aypay, 2015; Welch, 2005; Y1lmaz, 2007). In this regard, to maximize the faculty's intellectual leadership within all dimensions, higher education policy makers should update tenure criteria by adding new ways to promote the faculty's publication performance related to their financial contributions to the research projects, valuation of their institutional service, and the effectiveness of their community engagement activities. Moreover, university managers can re-arrange the promotion and reward systems in their universities by including the faculty's contributions to the solution of social problems; collaboration with different community actors; the attendance in national or international academic events; the dissemination of disciplinary related expert opinions to the media; the participation in local, national, regional or international research networks; the cooperation with industrial and business organizations; the membership of scientific committees; and the disciplinary pro-bono and gate-keeping activities besides the faculty's scholarly publications.

The impact of having managerial duties on the faculty's intellectual leadership was also investigated; building on previous results from Uslu (2015a), indicating the effects of faculty's personal, professional, and institutional features on their intellectual leadership. The findings in this research suggest that the faculty's managerial duties, especially at the top management levels, have a significantly strong effect on their intellectual leadership, particularly within the Ambassador and Advocate dimensions. This prominent differentiation between faculty with and without managerial duties may originate from academic managers' responsibilities related to representing their institutions in many external mediums both formally and informally (Yllmaz, 2007). In this regard, the faculty with managerial duties has more opportunities to raise social issues in different platforms more as formal voices, especially in institutionally printed and visual broadcasts (Macfarlane, 2012). Therefore, the academic administrators can share their official power by commissioning younger faculty with various managerial responsibilities. In addition, they can create academic formations related to social topics on institutional environment, which increases faculty's contribution to both institutional recognition and the community life. Finally, they can generate public campaign opportunities on institutional and social media platforms. 
Furthermore, when the impact of having managerial duties was controlled, the analysis results showed three ways that the female faculty differed. They displayed greater efforts to help the professional development of their less experienced colleagues, to oversee the disciplinary standards in their colleagues' studies, and to represent their institutions in different mediums. These differences might be explained as follows: the female faculty, because of their potentially higher emotional intelligence (Konakay, 2013), can act more empathically to encourage their less experienced colleagues to advance their careers (Uslu, 2015a). Moreover, the female faculty, as a well-known fact, mostly works in subjective science areas (e.g., arts and humanities and social sciences). Hence, they try more often to contribute to the collective wisdom in their field by editing or reviewing the studies of their colleagues and students, as well as representing their institutions as a panelist, chair, and committee member (Welch, 2005). Accordingly, to increase the collaboration of the faculty, especially the male ones, with their younger colleagues, university managers should develop varied practices such as official mentorship programs. They can also enhance male faculty's contributions at least to the institutional research and publication mechanisms by assigning them as editors, reviewers, panelists, or committee members more often than female faculty.

Additionally, covariance analyses, after controlling the impact of having managerial duties, reported that the full-time professors displayed intellectual leadership behaviors more often than the junior faculty. Uslu (2015a) also found that there were significant differences among the faculty's intellectual leadership behaviors within the Acquisitor, Guardian, and Advocate dimensions in terms of both seniority and academic title, in favor of professors. These findings reveal that, during their longer tenure, professors have more opportunities to serve their disciplines, institutions and community by using their scientific expertise in various ways such as helping the professional development of junior colleagues, keeping up standards in their disciplines, gaining different research supports, and improving social wellness (Macfarlane, 2011; Macfarlane, 2012; Rayner et al., 2010). To minimize the differences between the highly experienced and younger faculty's intellectual leadership, university managers may institute several institutional practices such as official leadership trainings for younger faculty, giving priority for less experienced faculty to attend international exchange programs, larger travel funds for junior faculty to attend scholarly events, creating inducement project opportunities for early career faculty, and operating co-advisory system by jointly senior and younger faculty.

The researcher also analyzed the differences among the faculty's intellectual leadership in terms of their disciplines by equalizing the impact of having managerial duties and found that faculty who work in social sciences are more active in displaying behaviors within the Mentor, Guardian, and Advocate dimensions, while faculty from natural sciences exhibit greater efforts to obtain competitive research funds to finance their groups' projects. Likewise, Uslu (2015a; 2015b) stated that the displayed level of the intellectual leadership of the faculty from social sciences was higher than that of the faculty from other disciplines. Aypay (2001) also explored that being an academic in the high consensus disciplines (e.g., astronomy, botany, biology, chemistry, geology, math, microbiology, physiology, physics, and zoology) had a negative influence on the Scholarship of Integration (e.g., publication of reviews and interdisciplinary work, publications for society, service to local organizations, and lectures in local organizations). In line with these results, it might be supposed that while knowledge production is much more mechanical in some disciplines, social sciences are composed of more subjective disciplines; this provides the faculty from social sciences more opportunities to use their expertise about social issues in different public mediums. This interaction capacity for the faculty from social sciences encourages them to display wider leadership behaviors to keep up the standards of their disciplines, to transfer their disciplinary values to early career colleagues, and to adapt their knowledge in the solutions of problems in society. Therefore, university managers should encourage faculty from primarily product-oriented disciplines to embrace Advocate behaviors by participating debates and activities related to social affairs. Moreover, to augment the 
intellectual leadership behaviors of faculty from different disciplines by increasing their collaboration, university managers can initiate various inter-disciplinary research units and networks, form interdisciplinary post-graduate programs, and arrange seminars and workshops related to joint project preparation.

As a final result, by eliminating the impact of having managerial duties, this research reveals that faculty who work in pre-1992 universities, regardless of their locations, displayed more intellectual behaviors to acquire different funds and resources to disseminate their unique contributions to the development of new knowledge production methodologies in their disciplines, and to oversee the scientific standards in studies of their colleagues and students. Uslu (2015a; 2015b) also reported findings showed only the difference in the Acquisitor dimension in favor of the faculty from pre-1992 universities. Moreover, Macfarlane and Chan (2014) indicated that many obituaries, which were related to successful academics in different aspects of scholarship, mentioned mostly academics who studied in older universities. These results confirmed that the establishment dates of universities are the most relevant indicators to point out the development level of universities' academic and physical environment, and older universities generally have stronger institutional resources and infrastructure (e.g., broader libraries, techno-cities, technology transfer offices, advanced laboratories, powerful collaborations with industrial organizations, larger research funds, comprehensive doctorate programs, etc.) to facilitate the faculty's scholarly activities mostly within intellectual leadership (Aypay, 2015; Evans, 2012; Özoğlu et al., 2015). Therefore, it is possible to comment that the faculty who works in older universities provides more financial contributions to their universities than the faculty from younger universities through extensive research support facilities in their institutions. Therefore, it can be said that the faculty from older universities rapidly elaborates their disciplinary reputation by their advanced studies and then frequently take responsibilities in disciplinary associations, publications, and events within editorial, advisory, or supervisory boards and organization committees. Accordingly, to support the faculty's intellectual leadership behaviors especially within the context of their research and disciplinary activities, as well as instituting the essential infrastructure such as central research office, advanced laboratories, technology production hubs, and extensive library facilities with various database access options, managers in younger universities may initiate supportive operations such as

- courses on academic writing in foreign languages,

- project preparation trainings,

- formal pre-review bodies for publications and project proposals,

- project management units in faculties,

- broader ethics committees in faculty and at university levels,

- institutional agreements to join international research networks,

- website announcements of internal and external research funds,

- newsletters about international exchange programs,

- sabbatical opportunities and travel funds,

- internal scholarships and fellowships to finance younger researchers,

- online platforms related to documents, materials, and equipment sharing among academics. 
In short, this research examined the differences among the displayed level of faculty's academic intellectual leadership behaviors according to their personal, professional, and institutional features. After controlling the impact of having managerial duties, several significant differences in the frequency of faculty's intellectual leadership behaviors in terms of their gender, seniority, title, discipline, and universities' establishment dates are reported. However, the research sample was composed of faculty from varied Turkish public universities. To increase our understanding, researchers might carry out further studies related to academics' intellectual leadership on different study groups from selected higher education institutions. Moreover, the relations between academics' intellectual leadership and various institutional features of universities could be investigated by using different organizational behavior scales. Researchers may also explore the influence of academics' humanistic characteristics on their intellectual leadership by using different research methods. 


\section{References}

ARBIS (The Researcher Information System, Turkey). (2015). Researcher information inquiry platform. Retrieved July, 24, 2015, from https://arbis.tubitak.gov.tr

Arslan, H., \& Uslu, B. (2014). Öğretmen adaylarının öğrenme stilleri ile liderlik yönelimleri arasındaki ilişki. Eğitim ve Bilim, 39(173), 341-355.

Ary, D., Jacobs, L. C., Razavieh, A., \& Sorensen, C. (2006). Introduction to research in education (7th ed.). Belmont, CA: Thomson Wadsworth.

Aydın, İ. (2012, January 3). Intihal intiharı. Retrieved from http://www.haber7.com/.

Aypay, A. (2001). The relationship between organizational structures and faculty roles at colleges and universities (Unpublished doctoral dissertation). Vanderbilt University, Nashville-TN.

Aypay, A. (Ed.). (2015). Türkiye'de yükseköğretim: Alanı, kapsamı ve politikaları. Ankara: Pegem Akademi.

Bayat, N. (2014). Öğretmen adaylarının eleştirel düşünme düzeyleri ile akademik yazma başarıları arasındaki ilişki. Eğitim ve Bilim, 39(173), 155-168.

Boyer, E. L. (1990). Scholarship reconsidered: Priorities of the professoriate. New York: Carnegie Foundation for the Advancement of Teaching.

Can, A. (2014). SPSS ile bilimsel araştırma sürecinde nicel veri analizi (3rd ed.). Ankara: Pegem Akademi.

Chynoweth, P. (2009). The built environment interdiscipline: A theoretical model for decision makers in research and teaching. Structural Survey, 27(4), 301-310. doi:10.1108/02630800910985090

Cohen, L., Manion, L., \& Morrison, K. (2007). Research methods in education (6th ed.). London: Routledge.

Delanty, G. (2001). The university in the knowledge society. Organization, 8(2), 149-153. doi:10.1177/1350508401082002

Evans, L. (2012). Leadership for researcher development: What research leaders need to know and understand. Educational Management Administration \& Leadership, 40(4), 423-435. doi:10.1177/1741143212438218

Evans, L., Homer, M., \& Rayner, S. (2013). Professors as academic leaders: The perspectives of 'the led'. Educational Management Administration \& Leadership, 41(5), 674-689. doi:10.1177/1741143213488589

Field, A. (2009). Discovering statistics using SPSS (3th ed.). Thousand Oaks, CA: Sage Publication.

Hair, J. F., Black, W. C., Babin, B. J., \& Anderson, R. E. (2010). Multivariate data analysis (7th ed.). New Jersey: Pearson Prentice Hall.

İlhan, M., \& Çetin, B. (2014). Sınıf Değerlendirme Atmosferi Ölçeği'nin (SDAÖ) geliştirilmesi: Geçerlik ve güvenirlik çalışması. Eğitim ve Bilim, 39(176), 31-50. doi:10.15390/EB.2014.3334

Kaplan, P. (2014, July 28). Akademisyenlerin 'atıf' çetesi. Retrieved from http://www.haberturk.com/.

Keskin, N., \& Burucu, K. (2013, June 30). Öğrencisine yetemeyen akademisyenlerimiz. Retrieved from http://www.hurriyet.com.tr/.

Konakay, G. (2013). Akademisyenlerde duygusal zekâ faktörlerinin tükenmişlik faktörleri ile ilişkisine yönelik bir araştırma: Kocaeli Üniversitesi örneği. Dokuz Eylül Üniversitesi Sosyal Bilimler Esntitüsü Dergisi, 15(1), 121-144.

Macfarlane, B. (2011). Professors as intellectual leaders: Formation, identity and role. Studies in Higher Education, 36(1), 57-73. doi:10.1080/03075070903443734

Macfarlane, B. (2012). Intellectual leadership in higher education: Renewing the role of the university professor. London: Routledge.

Macfarlane, B., \& Chan, R. Y. (2014). The last judgement: Exploring intellectual leadership in higher education through academic obituaries. Studies in Higher Education, 39(2), 294-306. doi:10.1080/03075079.2012.684679 
NCUP (National Conference of University Professors). (1991). The role of the professoriate. Retrieved from http://www.ncup.org.uk/?p=78

Northouse, P. G. (2007). Leadership: Theory and practice (4th ed.). Thousand Oaks, CA: Sage Publications.

Olssen, M., \& Peters, M. A. (2005). Neoliberalism, higher education and the knowledge economy: From the free market to knowledge capitalism. Journal of Education Policy, 20(3), 313-345. doi:10.1080/02680930500108718

Özoğlu, M., Gür, B. S., \& Gümüs, S. (2016). Rapid expansion of higher education in Turkey: The challenges of recently established public universities (2006-2013). Higher Education Policy, 29(1), 21-39. doi:10.1057/hep.2015.7

Rayner, S., Fuller, M., McEwen, L., \& Roberts, H. (2010). Managing leadership in the UK University: A case for researching the missing professoriate?. Studies in Higher Education, 35(6), 617-631. doi:10.1080/03075070903243100

Tight, M. (2002). What does it mean to be a professor? Higher Education Review, 34, 15-31.

Uslu, B. (2015a). Communication, climate and managerial flexibility regarding scholarly practices in universities, and faculty's academic intellectual leadership: A structural equation modeling (Unpublished doctoral dissertation). Çanakkale Onsekiz Mart University, Institute of Educational Sciences, Çanakkale.

Uslu, B. (2015b). Testing the psychometric features of the Academic Intellectual Leadership Scale in a university environment. Educational Sciences: Theory \& Practice, 15(6), 1605-1621. doi:10.12738/estp.2015.6.0205

Uslu, B., \& Arslan, H. (2015). Faculty's academic intellectual leadership: Predictive relations with several organizational characteristics of universities. Yükseköğretim ve Bilim Dergisi, 5(2), 125-135. doi:10.5961/jhes.2015.115

Welch, A. (Ed.). (2005). The professoriate: Profile of a profession. Dordrecht: Springer.

Yılmaz, H. (2007). Akademik yöneticilerin entelektüel düzeylerinin ölçülmesi (Unpublished doctoral dissertation). Kocaeli University, Institute of Social Science, Kocaeli.

YÖK (The Council of Higher Education, Turkey). (2015, July 23). The distribution of Turkish Faculty. Retrieved from https://istatistik.yok.gov.tr/ 